\title{
PATOMEKANISME PENYAKIT GAGAL JANTUNG KONGESTIF
}

\author{
Lailia Nur Rachma
}

\author{
Jurusan Biologi, Fakultas Sains dan Teknologi UIN Maliki Malang
}

\begin{abstract}
Heart failure is a clinical syndrome characterized by abnormalities in the structure or function of the heart, resulting in inability of heart to pump blood to meet the metabolic needs of the body tissue. Heart failure is characterized by clinical manifestations such as circulation congestion, tightness, fatigue, and weakness. Heart failure is a major problem in industrial and developing Country. Currently, the incidence and prevalence of heart failure tends to increase, it is also accompanied by an increase in mortality of heart failure cases. In the United States, 1 million patients hospitalized due to heart failure cases, which contribute to 50,000 deaths each year. While the number of visits to the hospital due to heart failure estimated at 6.5 million. Heart failure prognosis is generally poor despite the patients accepted adequate therapy. From the data obtained, only about $35 \%$ of male patients and $50 \%$ female patients who survived after the onset of acute heart failure. Generaly, the data obtained high mortality are occurs in patients with grade IV (presence of symptoms at rest) is about 30-70\%, grade III (presence of symptoms with mild activity) 10-20\%, class II (presence of symptoms when the activity being 5-10 $\%)$. Higher mortality was found in older patients, men, patients with reduced ejection fraction, and in patients with coronary disease. Once someone is suffering from heart failure, then he shall bear the very high cost. In America, the cost of issued for heart failure therapy between 15-40 trillion US\$. In this review, we will discuss about pathomechanism of heart failure. So it is expected to be a reference to the diagnosis of patients with heart failure, which is expected to be recognized early on that could ultimately improve the quality of heart failure patient life, and reduce the number of mortality due to heart failure.
\end{abstract}

\section{Pendahuluan}

Gagal jantung adalah sindroma klinik yang ditandai oleh adanya kelainan pada struktur atau fungsi jantung yang mengakibatkan jantung tidak dapat memompa darah untuk memenuhi kebutuhan metabolisme jaringan. Gagal jantung ditandai dengan manifestasi klinik berupa kongesti sirkulasi, sesak, fatigue dan kelemahan. Gagal jantung masih merupakan masalah utama dalam negara industri (Kasper et al., 2004). Baru-baru ini didapatkan bahwa Congestive Heart Failure terkait dengan penurunan kardiak output dan vasokonstriksi perifer yang berlebihan (Haji dan Mohaved, 2000).

Gagal jantung sering diakibatkan karena adanya defek pada kontraksi miokard atau diakibatkan karena abnormalitas dari otot jantung seperti pada kasus kardiomiopati atau viral karditis (Kasper et al., 2004). Gagal jantung karena disfungsi miokard mengakibatkan kegagalan sirkulasi untuk mensuplai kebutuhan metabolisme jaringan. Hal ini biasanya diikuti kerusakan miokard bila mekanisme kompensasi gagal. Penyebab kerusakan pada miokard antara lain infark miokard, stress kardiovaskular (hipertensi, penyakit katub), toksin (konsumsi alkohol), infeksi atau pada beberapa kasus tidak diketahui penyebabnya (Crawford, 2002). Penyebab lain adalah arteroskerosis pada koroner, congenital, kelainan katub, hipertensi atau pada kondisi jantung normal dan terjadi peningkatan beban melebihi kapasitas, seperti pada krisis hipertensi, ruptur katub aorta dan pada endokarditis dengan masif emboli pada paru. Dapat pula terjadi dengan fungsi sistolik yang normal, biasanya pada kondisi kronik, misal mitral stenosis tanpa disertai kelainan miokard (Kasper et al., 2004). 
Insiden dan prevalensi gagal jantung cenderung meningkat, hal ini juga disertai dengan peningkatan mortalitas (Saunders, 2000). Di Amerika Serikat 1 juta pasien rawat inap akibat gagal jantung, dan memberikan kontribusi 50.000 kematian tiap tahunnya (Kasper et al., 2004) dan angka kunjungan ke rumah sakit sebanyak 6,5 juta akibat gagal jantung (Hunt et al.,2005) Dari tahun 19901999 didapatkan peningkatan rawat inap karena gagal jantung dari 810 ribu menjadi lebih dari 1 juta dengan diagnosis primer, dan dari 2,4 juta menjadi 3,6 juta yang didiagnosis gagal jantung primer atau sekunder. Tahun 2001 didapatkan angka kematian sebesar 53 ribu dengan gagal jantung sebagai penyebab primer. Didapatkan pula kecenderungan peningkatan insiden gagal jantung pada usia tua, hipertensi, dislipidemia, dan diabetes. Insiden gagal jantung pada usia < 45 tahun 1/1000, meningkat menjadi 10/1000 pada usia > 65 tahun, dan menjadi 30/1000 (3\%) pada usia $>85$. Didapatkan peningkatan secara eksponenstial sesuai dengan peningkatan usia, 0,1 \% range antara 50-55 tahun dan menjadi $10 \%$ pada usia $>80$ tahun. Di Amerika didapatkan prevalensi sebesar 4,8 juta, dan sekitar $75 \%$ dengan usia > 65 tahun. Insiden dan prevalensi gagal jantung didapatkan lebih tinggi pada wanita, didapatkan perbandingan $1 / 2$, hal ini diperkirakan karena angka harapan hidup pada wanita lebih lama (Saunders, 2000). Walaupun dengan terapi yang adequate namun angka kematian akibat Gagal jantung cenderung tetap (Hunt et al., 2005).

Prognosis pasien gagal jantung buruk walaupun dengan terapi yang adequate. Data yang diperoleh sekitar $35 \%$ pasien pria bertahan hidup setelah onset akut gagal jantung dan 50\% pada wanita. Secara umum didapatkan data mortalitas pada klas IV (adanya symptom saat istirahat) sekitar 30-70\%, klas III (adanya symptom dengan aktiviitas ringan) 10-20\%, klas II (adanya symptom saat aktivitas sedang $5-10 \%$. Mortalitas lebih tinggi didapatkan pada pasien lebih tua, laki-laki, penurunan fraksi ejeksi dan adanya penyakit koroner. Biaya yang dikeluarkan untuk terapi gagal jantung di Amerika antara 15-40 trilyun US\$ (Saunders, 2000).

Gagal jantung sebenarnya bukan istilah yang tepat, karena hal ini memiliki beberapa interpretasi dan menggambarkan beberapa kondisi klinik yang berbeda. Gagal jantung kanan atau kiri memiliki karakteristik yang berbeda namun seringkali muncul secara bersamaan (Warrell et al., 2003). Gagal jantung merupakan sindroma klinik yang komplek yang diakibatkan oleh adanya kelainan struktur atau fungsional yang mengakibatkan ventrikel tidak dapat memompa darah secara adekuat untuk memenuhi kebutuhan metabolisme jaringan. Tanda cardinal dari gagal jantung adalah dyspnea dan fatigue yang menyebabkan keterbatasan aktivitas, serta retensi cairan yang dapat menyebabkan odema paru atau odema peripheral. Kedua gangguan ini mengakibatkan penurunan kapasitas fungsional dan penurunan kualitas hidup individu, namun keduanya tidak harus didapatkan secara bersamaan. Pada beberapa pasien hanya didapatkan intoleransi dalam olahraga namun tidak didapatkan gejala retensi cairan. Gejala gagal jantung dapat diakibatkan karena adanya kelainan pada pericardium, myocardium, endokardium atau pada pembuluh darah besar, namun sebagian besar pasien didapatkan gejala karena adanya impairment pada miokard ventrikel kiri. Gagal jantung terkait dengan abnormalitas pada ventrikel kiri dengan range mulai dari ukuran ventrikel kiri normal dengan fraksi ejeksi yang normal dengan disertai vasodilatasi yang berat atau menurun. Pada kebanyakan pasien didapatkan kelainan pada sistolik dan diastolic disamping adanya gangguan pada fraksi ejeksi. Pasien dengan fraksi ejeksi yang normal memerlukan terapi yang berbeda dengan yang mengalami penurunan fraksi ejeksi, walaupun hal ini masih kontroversial. Penyebab Gagal jantung yang lain adalah arterosclerosis koroner, hipertensi atau kardiomiopati, kelainan katub, dan segala kelainan pada jantung (Hunt et al., 2005)

Klasifikasi terbaru adalah berdasarkan pola disfungsi ventrikel, yaitu adanya gangguan pada sistolik, diastolic atau pada keduanya, dan klasifikasi ini terbukti efektif. Patofisiologi gagal jantung akibat kelainan pada ventrikel sangat komplek. Gejala klinis yang dapat dikategorikan sebagai gagal jantung adalah dimulai dengan penurunan effective cardiovascular functional reserve, adanya gejala saat istirahat atau dengan sedikit aktivitas, dan perubahan karakteristik patofisiolagi pada system organ, antara lain biokimia, hormonal, metabolik atau perubahan fungsi. Jadi dengan kata lain gagal jantung merupakan sindrome yang ditandai dengan penurunan fungsi ventrikel kiri karena suatu proses patofisiologi tertentu yang menimbulkan gejala dan keterbatasan aktivitas. 
Terdapat dua mekanisme yang menyebabkan pengurangan pada cadiac output dan kegagalan jantung yaitu disfungsi sistolik dan disfungsi diastolik. Penyebab tersering dari disfungsi sistolik adalah penyakit jantung iskemik, idiopatik kardiomyopathy, hipertensi, dan penyakit katup jantung. Disfungsi diastolik dapat terjadi pada $40-50 \%$ pasien dengan kegagalan jantung, lebih sering terjadi pada wanita, dan frekuensi akan semakin meningkat seiring dengan penambahan usia. Disfungsi diastolik dapat terjadi pada beberapa kondisi yang menyebabkan disfungsi sistolik. Penyebab tersering dari disfungsi sistolik ini adalah hipertensi, penyakit jantung iskemik, hipertropik kardiomiopati, dan restriktif kardiomiopati (Figueroa dan Peters, 2006)

Sedangkan tanda yang biasanya akan tampak pada pasien dengan congestive gagal jantung adalah letak apek jantung yang terletak lebih lateral (akibat pembesaran dari jantung), adanya gallop rhytm. Suara murmur mengindikasikan adanya penyakit pada katup jantung, misalkan regurgitasi aorta, atau mitral stenosis. Kegagalan pada jantung kiri memberikan tanda berupa takipnea, rales atau crackles yang mana mengindikasikan telah terjadinya edema pulmonary, perkusi yang redup pada area paru dan penurunan suara nafas terutama pada basal paru mengindikasikan telah terjadinya efusi pleura, dan terjadinya sianosis akibat penurunan difusi oksigen pada kapiler pulmonary (Medical Criteria, 2005)

\section{Etiologi Gagal Jantung}

Berbagai gangguan penyakit jantung yang mengganggu kemampuan jantung untuk memompa darah menyebabkan gagal jantung yang biasanya diakibatkan karena kegagalan otot jantung yang menyebabkan hilangnya fungsi yang penting setelah kerusakan jantung, keadaan hemodinamis kronis yang menetap yang disebabkan karena tekanan atau volume overload yang menyebabkan hipertrofi dan dilatasi dari ruang jantung, dan kegagalan jantung dapat juga terjadi karena beberapa faktor eksternal yang menyebabkan keterbatasan dalam pengisian ventrikel.

\section{Patofisiologi Congestive Heart Failure (CHF)}

Jantung adalah organ berupa otot, berbentuk kerucut, berongga dan dengan basisnya di atas dan puncaknya di bawah. Apexnya (puncak) miring ke sebelah bawah kiri. Berat jantung kira-kira 300 gram. Agar jantung dapat berfungsi sebagai pompa yang efisien, otot-otot jantung di bagian atas dan bawah akan berkrontraksi secara bergantian. Laju denyut jantung atau kerja pompa ini dikendalikan secara alami oleh suatu pengatur irama (pace maker) yang di sebut nodus sinoarterial. Nodus sinoarterial ini terletak di dalam dinding serambi kanan. Sebuah impuls listrik yang ditransmisikan dari nodus sinoarterial ke kedua serambi membuat keduanya berkontraksi secara serentak. Arus listrik ini selanjutnya di teruskan ke dindingdinding bilik, yang pada gilirannya membuat bilik-bilik berkontraksi secara serentak. Periode kontraksi ini disebut sistol. Selanjutnya periode ini diikuti dengan sebuah periode rilaksasi pendek - kira-kira 0.4 detik - yang disebut diastole, sebelum impuls berikutnya datang. Nodus sinoarterial menghasilkan antara 60-72 impuls seperti ini setiap menit ketika jantung sedang santai. Produksi impuls-impuls ini juga dikendalikan oleh satu bagian sistim syaraf yang disebut sistim syaraf otonom, yang bekerja di luar keinginan kita. Sistim listrik built up inilah yang menghasilkan kontraksikontraksi otot jantung berirama yang disebut denyut jantung.

Terdapat tiga kondisi yang mendasari terjadinya gagal jantung, yaitu gangguan mekanik (beberapa faktor yang mungkin bisa terjadi secara tunggal atau bersamaan yaitu beban tekanan, beban volume, tamponade jantung atau kontriksi perikard, jantung tidak dapat diastole, obstruksi pengisian ventrikel, aneurisme ventrikel, disenergi ventrikel, restriksi endokardial atau miokardial) dan abnormalitas otot jantung yang terdiri dari primer (kardiomiopati, miokarditis metabolic (DM, gagal ginjal kronik, anemia) toksin atau sitostatika) dan sekunder (iskemia, penyakit sistemik, penyakit infiltrative, dan korpulmonal).

1. Gangguan irama jantung atau konduksi Menurut Soeparman (2000) beban pengisian (preload) dan beban tekanan (afterload) pada ventrikel yang mengalami dilatasi atau hipertrofi memungkinkan adanya peningkatan daya kontraksi jantung yang lebih kuat, sehingga curah jantung meningkat. Pembebanan jantung yang lebih besar meningkatkan simpatis, sehingga kadar katekolamin dalam darah meningkat dan terjadi takikardi dengan tujuan meningkatkan curah jantung. Pembebanan jantung yang berlebihan 
dapat mengakibatkan curah jantung menurun, maka akan terjadi redistribusi cairan dan elektrolit (Na) melalui pengaturan cairan oleh ginjal dan vasokontriksi perifer dengan tujuan untuk memperbesar aliran balik vena (venous return) ke dalam ventrikel sehingga meningkatkan tekanan akhir diastolic dan menaikkan kembali curah jantung (Soeparman, 2001).

Dilatasi, hipertrofi, takikardi, dan redistribusi cairan badan merupakan mekanisme kompensasi untuk mempertahankan curah jantung dalam memenuhi kebutuhan kompensasi untuk mempertahankan curah jantung dalam memenuhi kebutuhan sirkulasi badan. Bila semua kemampuan mekanisme kompensasi jantung tersebut di atas sudah dipergunakan seluruhnya dan sirkulasi darah dalam badan belum juga terpenuhi, maka terjadilah keadaan gagal jantung (Rang, 2003)

Gagal jantung kiri atau gagal jantung ventrikel kiri terjadi karena adanya gangguan pemompaan darah oleh ventrikel kiri sehingga curah jantung kiri menurun dengan akibat tekanan akhir diastole dalam ventrikel kiri dan volume akhir diastole dalam ventrikel kiri meningkat. Keadaan ini merupakan beban atrium kiri dalam kerjanya untuk mengisi ventrikel kiri pada waktu diastolic, dengan akibat terjadinya kenaikan tekanan rata-rata dalam atrium kiri. Tekanan dalam atrium kiri yang meninggi ini menyebabkan hambatan aliran masuknya darah dari vena-vena pulmonal. Bila keadaan ini terus berlanjut, maka bendungan akan terjadi juga dalam paruparu dengan akibat terjadinya edema paru dengan segala keluhan dan tanda-tanda akibat adanya tekanan dalam sirkulasi yang meninggi. Keadaan yang terakhir ini merupakan hambatan bagi ventrikel kanan yang menjadi pompa darah untuk sirkuit paru (sirkulasi kecil). Bila beban pada ventrikel kanan itu terus bertambah, maka akan meransang ventrikel kanan untuk melakukan kompensasi dengan mengalami hipertropi dan dilatasi sampai batas kemempuannya, dan bila beban tersebut tetap meninggi maka dapat terjadi gagal jantung kanan, sehingga pada akhirnya terjadi akhirnya terjadi gagal jantung kiri-kanan. Gagal jantung kanan dapat pula terjadi karena gangguan atau hambatan pada daya pompa ventrikel kanan sehingga isi sekuncup ventrikel kanan tanpa didahului oleh gagal jantung kiri. Dengan menurunnya isi sekuncup ventrikel kanan, tekanan dan volume akhir diastole ventrikel kanan akan meningkat dan ini menjadi beban atrium kanan dalam kerjanya mengisi ventrikel kanan pada waktu diastole, dengan akibat terjadinya kenaikan tekanan dalam atrium kanan. Tekanan dalam atrium kanan yang meninggi akan menyebabkan hambatan aliran masuknya darah dalam vena kava superior dan inferior ke dalam jantung sehingga mengakibatkan kenaikan dan adanya bendungan pada vena-vena sistemik tersebut (bendungan pada vena jugularis dan bendungan hepar) dengan segala akibatnya (tekanan vena jugularis yang meninggi dan hepatomegali). Bila keadaan ini terus berlanjut, maka terjadi bendungan sistemik yang lebih berat dengan aakibat timbulnya edema tumit atau tungkai bawah dan asites (Osama Gusbi, 2002).

Manifestasi CHF tidak hanya
disebabkan karena ketidakmampuan jantung dalam mensuplai oksigen yang adekuat ke jaringan perifer, tapi juga tergantung pada respon sistemik dalam mengkompensasi ketidakadekuatan suplai oksigen ke jaringan. Beberapa faktor yang menentukan cardiac output meliputi heart rate dan stroke volume. Stroke volume ditentukan oleh preload, kontraktilitas, dan afterload. Variabel-variabel ini penting diketahui dalam patofisiologis $\mathrm{CHF}$ dan potensi terapi. Selain itu interaksi kardiopulmonary penting juga untuk diketahui dalam peranannya dalam kegagalan jantung (Figueroa dan Peters, 2006). 


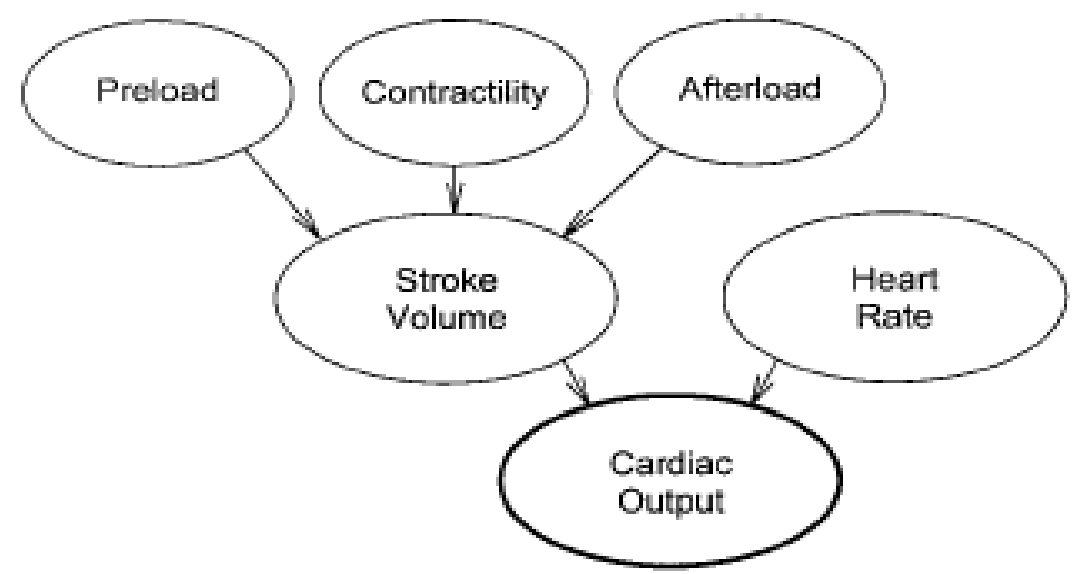

Gambar 1. Bagan determinan kardiak output (Storrow, 2007).

Preload dapat dilihat dari jumlah volume darah yang harus dipompa oleh jantung, kontraktilitas merupakan kemampuan memompa jamtung, sedangkan afterload merupakan kekuatan yang harus dikeluarkan oleh jantung untuk memompa darah. Preload tidak hanya dipengaruhi oleh volume intravaskuler, tapi juga dipengaruhi oleh keadaan restriksi saat pengisian ventrikel. Fungsi diastolic ditentukan oleh dua faktor yaitu elastisitas dari ventrikel kiri, yang mana merupakan fenomena yang pasif, dan relaksasi myocardial yang mana proses ini merupakan proses yang aktif dan membutuhkan energi. Ketidaknormalan ventrikel kiri untuk relaksasi atau elastisitasnya baik itu karena structural (contoh: hypertropi ventrikel kiri) atau perubahan pada fungsional (contoh: iskemia) mempengaruhi juga pengisian ventrikel (preload).

Variable kedua dari stroke volume adalah kontraktilitas jantung, Pada jantung normal fungsi sistolik fraksi ejeksi akan selalu dipertahankan diatas 50-55\%. Infark myokard akan menyebabkan myokard tidak dapat bekerja dengan baik, hal ini dikarenakan jantung tidak dapat berkontraksi dengan baik. Jaringan yang infark dapat diperbaiki dengan pembedahan atau dengan terapi obat-obatan. Beberapa hal yang juga mempengaruhi kontraktilitas jantung adalah agent farmakologik (calcium-channel blocker), hipoksemia, dan asidosis yang parah.

Variabel terakhir dari komponen stroke volume adalah afterload. Afterload biasanya dilihat dengan pengukuran mean arterial pressure. Afterload dipengaruhi oleh beberapa faktor yaitu tahanan vaskuler, dan tekanan intratorakal. Bersama-sama ketiga komponen ini saling mempengaruhi dalam patofisiologi CHF. Pada kondisi dimana terjadi penurunan cardiac output, maka heart rate atau stroke volume harus berubah untuk menjaga kelangsungan perfusi. Jika stroke volume tidak dapat dirubah, maka heart rate harus ditingkatkan untuk menjaga cardiac output (Figueroa dan Peters, 2006).

Sistem neurohormonal teraktivasi pada disfungsi ventrikel dengan penurunan cardiac output, terjadi aktivasi baroreseptor pada arkus aorta, sinus karotikus, dan ventrikel kiri. Baroreseptor ini menstimulasi pusat regulator vasomotor pada medula, yang mana kemudian mengaktivasi system saraf simpatis, arginin vasopressin, dan rennin-angiotensin aldosteron system. Aktivasi system saraf simpatis dapat terlihat dari adanya peningkatan kadar norepinephrin plasma, hasilnya dapat terlihat dari peningkatan heart rate, kontraktilitas myocardium, vasokonstriksi perifer. Renin angiotensin system teraktivasi pada kegagalan jantung, melalui mekanisme intrarenal, yang distimulasi oleh perubahan tekanan atau perubahan pada kadar sodium pada macula densa, yang kemudian menyebabkan terjadinya retensi sodium dan cairan (Tsutsui et al., 2007).

\subsection{Mekanisme kompensasi gagal jantung}

\subsubsection{Mekanisme Frank Starling}

Mekanisme Frank Starling

meningkatkan stroke volume berarti terjadi peningkatan volume ventrivuler end diastolic. Bila terjadi peningkatan pengisian diastolic, berarti ada peningkatan peregangan dari serat otot jantung, lebih optimal pada filament aktin dan myosin, dan hasilnya meningkatkan tekanan pada kontraksi berikutnya. Pada keadaan normal, mekanisme Frank Starling 
mencocokkan output dari dua ventrikel (Boron dan Boulpaep, 2005).

Pada gagal jantung, mekanisme Frank

Starling membantu mendukung kardiak output. Kardiak output mungkin akan normal pada penderita gagal jantung yang sedang beristirahat, dikarenakan terjadinya peningkatan volume ventricular end diastolic dan mekanisme Frank-Starling. Mekanisme ini menjadi tidak efektif ketika jantung mengalami pengisian yang berlebihan dan serat otot mengalami peregangan yang berlebihan (Boron dan Boulpaep, 2005).

Hal penting yang menentukan kosumsi energy otot jantung adalah ketegangan dari dinding ventricular. Pengisian ventrikel yang berlebihan menurunkan ketebalan dinding pembuluh darah dan meningkatkan ketegangan dinding pembuluh darah. Peningkatan ketegangan dinding pembuluh darah. Peningkatan ketegangan dinding pembuluh darah akan meningkatkan kebutuhan oksigen otot jantung yang menyebabkan iskemia dan lebih lanjut lagi adanya gangguan fungsi jantung (Loscalzo et al., 2008).

2.2.2 Aktivasi neurohormonal yang mempengaruihi sistem saraf simpatetik

Stimulasi system saraf simpatetik berperan penting dalam respon kompensasi menurun cardiac output dan pathogenesis gagal jantung. Baik cardiac sympathetic tone dan katekolamin (epinephrine dan norepinephrin) meningkat selama tahap akhir dari hamper semua bentuk gagal jantung. Stimulasi lansung irama jantung dan kontraktilitas otot jantung oleh pengaturan vascular tone, sistem saraf simpatetik membantu memelihara perfusi berbagai organ, terutama otak dan jantung (Loscalzo et al., 2008).

Aspek negatif dari peningkatan aktivitas system saraf simpatetik melibatkan peningkatan tahanan sistem vaskular dan kelebihan kemampuan jantung dalam memompa. Stimulasi simpatetik yang berlebihan juga menghasilkan penurunan aliran darah ke kulit, otot, ginjal, dan organ abdominal. Hal ini tidak hanya menurunkan perfusi jaringan tetapi juga berkontribusi meningkatkan sistem tahanan vaskular dan stres berlebihan dari jantung (Rang, 2003).

\subsubsection{Mekanisme \\ Renin-Angiotensin-}

Aldosteron
Salah satu efek yang paling penting dalam menurunkan cardiac output dalam gagal jantung adalah reduksi aliran darah pada ginjal dan kecepatan filtrasi glomerulus, yang menyebabkan retensi garam dan air. Penurunan aliran darah ke ginjal, meningkatkan sekresi renin oleh ginjal yang secara paralel akan meningkatkan pula angiotensin II. Peningkatan konsentrasi angiotensin II berkontribusi pada keadaan vasokonstriksi dan menstimulasi produksi aldosteron dari adrenal korteks. Aldosteron akan meningkatkan reabsorpsi natrium dengan meningkatkan retensi air (Tsutsui et al., 2007).

Selain itu angiotensin II dan aldosteron juga terlibat dalam inflamasi proses perbaikan karena adanya kerusakan jaringan. Keduanya menstimulasi produksi sitokin, adhesi sel inflamasi (contoh neutrofil dan makrofag) dan kemotaksis; mengaktivasi makrofag pada sisi kerusakan dan perbaikan; dan menstimulasi pertumbuhan fibroblas dan sintesis jaringan kolagen (Loscalzo et al., 2008).

2.2.4 Peptida natriuretik dan substansi vasoaktif yang diproduksi secara lokal

Ada tiga jenis natriuretic peptide yaitu atrial natriuretic peptide (ANP), brain natriuretic peptide (BNP), dan C-type natriuretic peptide (CNP). ANP dihasilkan dari sel atrial sebagai respon meningkatkan ketegangan tekanan atrial, memproduksi natriuresis cepat dan sementara, diuretik dan kehilangan kalium dalam jumlah sedang dalam urine. BNP dikeluarkan sebagai respon tekanan pengisian ventrikel sedangkan fungsi CNP masih belum jelas.

\subsubsection{Hipertrofi otot jantung dan remodeling} Perkembangan hipertrofi otot jantung dan remodeling merupakan salah satu mekanisme akibat meningkatnya kerja yang berlebih. Meskipun hipertrofi ventrikel memperbaiki kerja jantung, ini juga merupakan faktor risiko yang penting bagi morbiditas dan mortalitas. Keadaan hipertrofi dan remodeling dapat menyebabkan perubahan dalam struktur (massa otot, dilatasi chamber) dan fungsi (gangguan fungsi sistolik dan diastolik). Ada 2 tipe hipertrofi, yaitu pertama Concentric hypertrophy, terjadi penebalan dinding pembuluh darah, disebabkan oleh hipertensi.dan kedua Eccentric hypertrophy, terjadi peningkatan panjang otot jantung 
disebabkan oleh dilated cardiomyopathy (Shigeyama et al., 2005).

\subsection{Diagnosa CHF}

Pendekatan pada pasien dengan kecurigaan kegagalan jantung meliputi riwayat dan pemeriksaan fisik, foto toraks, dan serangkaian tes yang harus dijalani. Riwayat penyakit sendiri kurang dapat dipakai dalam menegakkan diagnosa kegagalan jantung, tapi sering kali dapat memberi petunjuk penyebab dari kegagalan jantung, faktor yang memperberat, dan keparahan dari penyakit. Gejala gagal jantung dapat dihubungkan dengan penurunan cardiac output (mudah lelah, dan kelemahan) atau retensi cairan (dyspnea, orthopnea, dan "cardiac wheezing"). Pada kasus dengan kegagalan pada jantung kanan dapat menyebabkan terjadinya kongetif hepar. Retensi cairan juga menyebabkan edema perifer dan asites. Kegagalan pada jantung kiri dapt menyebabkan gejala berupa munculnya dyspnea on effort. Pulmonary congestion (dengan crackles dan wheezing) dominan muncul terutama pada keadaan akut maupun subakut (Osama, 2002)
Indikator yang dapat digunakan untuk mengetahui adanya overload volume adalah adanya peningkatan pada Jugular Venous Pressure. Pelebaran dari ventrikel dapat dilihat pada saat palpasi precordial, dan denyutan dari apex yang terletak lateral dari midclavicular line. Pada pasien dengan dispnea, maka gambaran foto thoraks akan sangat membatu untuk menetukan perkiraan penyebab dari dispnea tersebut, apakah diakibatkan karena kegagalan jantung atau karena penyakit pada paru-paru. Gambaran radiografi pada kelainan akibat kegagalan jantung adalah cardiomegali, cephalization dari pembuluh darah, peningkatan marker interstitial, dan adanya pleural efusi. Apabila didapatkan beberapa tanda, gejala, dan gambaran radiologi seperti yang disebutkan diatas maka diagnosa untuk $\mathrm{CHF}$ dapat ditegakkan. Pasien dengan riwayat penyakit jantung, diabetes melitus, hipertensi, atau riwayat penyakit arteri koroner meningkatkan resiko terkena CHF (Storrow, 2007). Untuk penegakan diagnosa CHF juga dapat menggunakan kriteria Framingham, seperti yang tertera pada tabel dibawah ini

Tabel 1. Kriteria Farmingham (Storrow, 2007)

\begin{tabular}{ll}
\hline Mfijor Criterif & Minor Criteria \\
\hline Paroxysmal Noctumal dyspnea & Ankle edema \\
Orthopnea & Night cough \\
Neck-vein distension & Dyspnea on exertion \\
Rales & Hepatomegaly \\
Cardiomegrly & Pleural Effision \\
Acute Pulmonary Edema & Vital capacity decreased $1 / 2$ from maximum \\
S3 Gallop & HR $120 /$ min \\
Increased venous pressure > $16 \mathrm{~cm}$ of water & \\
Circulation time $\geq 25$ sec & \\
Hepatojugular reflux & \\
Major or minor criteria & \\
Weight loss $\geq 4.5 \mathrm{~kg}$ in 5 days in response to treatment
\end{tabular}

\subsection{Pemeriksaan Penunjang 2.4.1. EKG}

Electrocardiography tidak dapat digunakan untuk mengukur anatomi LVH tetapi hanya merefleksikan perubahan elektrik (atrial dan ventrikular aritmia) sebagai faktor sekunder dalam mengamati perubahan anatomi. Hasil pemeriksaan ECG tidak spesifik menunjukkan adanya gagal jantung (Loscalzo et al., 2008).

\subsubsection{Radiologi}

Foto thorax dapat membantu dalam mendiagnosis gagal jantung. Kardiomegali biasanya ditunjukkan dengan adanya peningkatan cardiothoracic ratio / CTR (lebih besar dari 0,5) pada tampilan postanterior. Pada pemeriksaan ini tidak dapat menentukan gagal jantung pada disfungsi siltolik karena ukuran bias terlihat normal (National Clinical Guideline Centre, 2010). 


\subsubsection{Echocardiografi}

Pemeriksaan ini direkomendasikan untuk semua pasien gagal jantung. Tes ini membantu menetapkan ukuran ventrikel kiri, massa, dan fungsi. Kelemahan echocardiography adalah relative mahal, hanya ada di rumah sakit dan tidak tersedia untuk pemeriksaan skrining yang rutin untuk hipertensi pada praktek umum (National Clinical Guideline Centre, 2010).

\subsection{Klasifikasi Gagal Jantung}

Selain menggunakan kriteria

Framingham, terdapat beberapa pembagian kriteria yang dipakai pada gagal jantung, diantaranya klassifikasi menurut New York Heart Association (NYHA), dan pembagian stage menurut American Heart Association. Klassifikasi fungsional yang biasanya dipakai menurut NYHA adalah (Figueroa dan Peters, 2006) :

Klas I : tidak ada keterbatasan dalam melakukan aktifitas apapun, tidak muncul gejala dalam aktivitas apapun.

Klas II : mulai ada keterbatasan dalam aktivitas, pasien masih bisa melakukan aktivitas ringan dan keluhan berkurang saat istirahat

Klas III : terdapat keterbatasan dalam melaksanakan berbagai aktivitas, pasien

merasa keluhan berkurang dengan istirahat.

Klas IV : keluhan muncul dalam berbagai aktivitas, dan tidak berkurang meskipun dengan istirahat.

Sedangkan pada tahun 2001, the American College of Cardiology/American Heart Association working group membagi kegagalan jantung ini menjadi empat stage (Figueroa dan Peters, 2006):

Stage A : memiliki resiko tinggi untuk terkena CHF tapi belum ditemukan adanya kelainan struktural pada jantung

Stage B : sudah terdapat kelainan struktural pada jantung, akan tetapi belum menimbulkan gejala.

Stage C : adanya kelainan struktural pada jantung, dan sudah muncul manifestasi gejala awal jantung, masih dapat diterapi dengan pengobatan standard.
Stage D : pasien dengan gejala tahap akhir jantung, dan sulit diterapi dengan pengobatan standard.

\subsection{Terapi CHF}

\section{TERAPI PERTAMA}

Yang dapat dilakukan adalah mengoreksi atau stabilisasi berbagai keabnormalan yang terjadi yang dapat menginduksi munculnya CHF, misalkan iskemia dapat dikontrol dengan terapi medis atau pembedahan, hipertensi harus selalu terkontrol, dan kelainan pada katup jantung dapat ditangani dengan perbaikan pada katup tersebut (National Clinical Guideline Centre, 2010).

\section{TERAPI NON FARMAKOLOGIS}

Dapat dilakukan dengan restriksi garam, penurunan berat badan, diet rendah garam dan rendah kolesterol, tidak merokok, olahraga (National Clinical Guideline Centre, 2010).

\section{TERAPI FARMAKOLOGIS}

I. Diuretics

II. Vasodilator Drugs

$\checkmark$ Nitrate (isosorbide)

$\checkmark$ Hydralazine (terutama apabila ditambah dengan regimen digoxin dan terapi diuretic)

$\checkmark$ Ace inhibitors (captopril, enalapril) : obat ini bekerja dengan menghambat conversi angiotensin 1 menjadi angiotensin 2 melalui angiotensinconverting enzyme (ACE).

$\checkmark$ ACE2 reseptor blocker (losartan) : obat ini mengeblok reseptor A2, menyebabkan vasodilatasi dan menghambat proliferasi dari sel otot. Obat ini biasanya digunakan pada pasien yang intolerance terhadap ACE inhibitor, akibat efek samping yang dapat ditimbulkan yaitu batuk. (National Clinical Guideline Centre, 2010).

III. Inotropic Drugs Digitalis glycosides (digoxin)

IV. Beta blockers

Obat ini memiliki fungsi untuk memperbaiki fungsi ventrikel kiri, gejala, dan functional class, serta memperpanjang survival dari pasien CHF.beta blocker juga memiliki peranan dalam memodifikasi cytokine (interleukin-10, tumor necrosis alpha (TNF-alpha) dan soluble TNF reseptor 
(sTNF-R-1 dan R2) pada pasien dengan kardiomiopati (Shigeyama et al., 2005) Indikasi pemakaian beta blocker:

a. Pasien yang tergolong dalam klas II dan III , klasifikasi NYHA.

b. Hindari terapi ini pada pasien dengan NYHA klas I atau IV.

c. Sebelum menambahkan beta blocker, pastikan bahwa pasien stabil dan dalam terapi standard gagal jantung.

d. Mulai pemakaian terapi betablocker dengan memakai dosis rendah (carvedilol $3.125 \mathrm{mg}$ PO bid; metoprolol CR/XL, $12.5 \mathrm{mg}$ PO qd; bisoprolol, $1.25 \mathrm{mg}$ PO qd)

e. tingkatkan dosis dengan interval waktu 2 sampai 3 minggu (carvedilol, 25-50 mg PO bid; metoprolol CR/XL, $200 \mathrm{mg}$ PO qd; bisoprolol, $10 \mathrm{mg}$ PO qd)

Kontraindikasi pemakaian beta blocker terapi pada CHF:

$\checkmark$ Peningkatan berat badan

$\checkmark$ Peningkatan dosis diuretic

$\checkmark$ Kebutuhan untuk diuretik intravena ataupun obat inotropik

$\checkmark$ Didapatkan keadaan yang kian memburuk dari $\mathrm{CHF}$

$\checkmark$ Bronchial asma atau emphysema

$\checkmark$ Bradycardi

$\checkmark$ Hipotensi

$\checkmark$ Blok jantung derajat pertama dan ketiga

V. Aldosterone antagonis contoh spironolactone sebaiknya dipertimbangkan pada pasien dengan gagal jantung berat dan tidak ada kecurigaan adanya renal insufficiency atau hiperkalemia.

VI. Antiarrhythmic Therapy

VII. Anticoagulant Therapy (untuk mengurangi resiko terjadinya emboli pada pasien dengan atrial fibrilasi, tapi tidak diindikasikan pada pasien yang aktif dan tidak punya riwayat emboli)

4. TERAPI INFASIF

a) Coronary Reperfusion, terutama pada akut gagal jantung berulang dihubungkan dengan edema pulmonary.

b) Valvular Heart Disease.

c) Reduction ventriculoplasty meliputi eksisi pada bagian dari otot ventrikel kiri yang diskinetik. Hal ini biasanya dilakukan pada gagal jantung klas akhir.

d) Transmyocardial laser revascularization

e) Prosedur operasi perbaikan fungsi jantung

a. intra-aortic balloon pump

b. permanent implantable balloon pump

c. total artificial heart

f) Transplantasi Jantung (terapi paling efektif pada keadaan gagal jantung berat). 


\section{Daftar Pustaka}

Kasper DL, Braunwald E, Fauci A, Hauser S Longo D and Jameson JL. 2004. Harrison's Principles of Internal Medicine 16th Edition. Publisher: McGraw-Hill Professional, pp. 13671377.

Crawford MH. 2002. Current Diagnosis \& Treatment in Cardiology 2nd Ed. Publisher McGraw-Hill/Appleton \& Lange, pp. 23-30.

Saunders WB. 2000. Goldman: Cecil Textbook of Medicine, 21st ed. Publisher: W. B. Company, pp.74-80.

Haji S and Movahed A. 2000. Update on Digoxin Therapy in Congestive Heart Failure. American Family Physician vol 62 no 2.

Hunt et all. 2005. Heart Failure in the Adult: A Report of the American College of Cardiology/American Heart Association Task Force on Practice Guidelines (Writing Committee to Update the 2001 Guidelines for the Evaluation and American Management of Heart Failure): Developed in Collaboration With the College of Chest Physicians and the International Society for Heart and Lung Transplantation: Endorsed by the Heart Rhythm Society. Journal of The American Heart Association.

Warrell et all. 2003. Oxford Textbook of Medicine 4th edition. Publisher: Oxford Press, pp.305-320.

Figueroa MS and Peters JI. 2006. Congestive Heart Failure: Diagnosis, Pathophysiology, Therapy, and Implications for Respiratory Care. Respir Care. 51(4), pp. 403- 412.

Storrow AB. 2007. Advances in the diagnosis of chf: new markers. Modern Advances In Emergency Cardiac Care, p. 38-46.

Medical CRITERIA. 2005. Framingham Criteria for Congestive Heart Failure. In turn citing: Framingham study 1971.

Soeparman. 2001. Ilmu Penyakit Dalam. Jilid 11. Ed 3. Jakarta : FKUI.

Rang, HP. 2003. Pharmacology. Edinburgh: Churchill Livingstone. p. 127. ISBN 0 443-07145-4.

Osama GMD. 2002. Topic Review - Heart Failure. Albany Medical Review. January 2002.
Tsutsui H, Matsushima S, Kinugawa S, et al. May 2007. Angiotensin II type 1 receptor blocker attenuates myocardial remodeling and preserves diastolic function in diabetic heart. Hypertens. Res. 30(5): 439-49.

Boron, Walter F.; Boulpaep, Emile L. 2005. Medical Physiology: A Cellular and Molecular Approach(Updated ed.). Saunders. p. 533.

Loscalzo, Joseph; Fauci, Anthony S.; Braunwald, Eugene; Dennis L. Kasper; Hauser, Stephen L; Longo, Dan L. (2008). Harrison's Principles of Internal Medicine 17 ed.). McGrawHill Medical. ISBN 978-0-07-147693$\underline{5}$.

Shigeyama J, Yasumura Y, Sakamoto A, et al. 2005. Increased gene expression of collagen Types I and III is inhibited by beta-receptor blockade in patients with dilated cardiomyopathy. Eur. Heart J. 26 (24): 2698-705.

National Clinical Guideline Centre. 2010. Chronic Heart Failure: National Clinical Guideline for Diagnosis and Management in Primary and Secondary Care: Partial Update. National Clinical Guideline Centre: 34-47. 